\title{
State of the timeshare industry in Aruba - A call for research
}

Received (in revised form): 29 June 2007

\section{Jeeyeon Hahm}

is a PhD student in Hospitality Education at the Rosen College of Hospitality Management at the University of Central Florida. He has first-hand knowledge of the timeshare industry at the property management level.

\section{Earney Lasten}

is a PhD student in Hospitality Education at the Rosen College of Hospitality Management at the University of Central Florida. He has researched timeshare development growth patterns in Aruba.

\section{Randall S. Upchurch}

is the Director for the Center for Distributed Learning at the University of Central Florida and previous holder of the American Resort Development Association (ARDA) Professorship in Timeshare Resort Management. He is editor of ARDA's Timeshare Industry Resource Manual and the author of Timeshare Resort Operations as published by Elsevier.

\section{Ryan Peterson}

is the Dean of the Faculty of Hospitality \& Tourism Management Studies at the University of Aruba. As Dean Dr Peterson recognises the unique and strategic contribution of the hospitality and tourism industry to the overall development of Aruba and the region. Therefore, a primary goal of this programme is to develop strategic and dynamic competencies in hospitality and tourism management and, in addition, to strive for excellence in the Aruban hospitality and tourism industry.

\section{Abstract}

This case study is based on secondary data gathered concerning the state of the timeshare industry in Aruba. The major findings of this study indicate that there is a strong and growing consumer interest in timeshare ownership as a viable recreational alternative. This interest suggests that considerable empirical research is needed to understand the factors associated with sustaining the financial and economic impacts of the timeshare industry upon Aruba's economy.

\section{Keywords:}

timeshare resorts, Aruba, impacts, call for research, tourist destination

Journal of Retail and Leisure Property (2007) 6, 221-229.

Randall S. Upchurch Center for Distributed Learning University of Central Florida 3100 Technology Parkway Partnersip II Suite 234 Orlando, Florida 32816-3281 USA

Tel: +14078234910

Fax: +1 4072074911

E-mail: rupchurc@mail.ucf.edu doi:10.1057/palgrave.rlp.5100066

\section{INTRODUCTION}

The timeshare industry has been reported to have experienced a rapid and steadily growing impact in a variety of countries. ${ }^{1-5}$ Timeshare accommodations, also referred to as vacation ownership and vacation intervals, is the fastest growing segment of the travel and tourism 
industry. ${ }^{6-8}$ This growth in travel and tourism was highlighted in the 2006 report from the World Tourism Organization (WTO). ${ }^{7}$ The WTO noted that this growth was moderate in 2005 but was approximately oneand-a-half percentage points above the long-term average annual growth rate of 4.1 per cent for the travel and tourism industry noted in previous years. This sustained growth of the travel and tourism industry has been touted to be an artefact of the industry's constant innovation developed in response to consumer lifestyle needs and vacation preferences. ${ }^{9}$

One component of the travel and tourism industry that has sustained double-digit growth since inception is the timeshare resort industry. Timeshare resorts have become a preferred travel destination for many vacationers around the world..$^{8,10-12}$ The trend towards owning a unit within a timeshare resort for vacation and leisure purposes has been recognised by the WTO, the European Commission and other national tourist authorities. ${ }^{10}$ According to Resort Condominiums International's (RCI) 2003 report, Resort Timesharing Worldwide of 2003, there were more than 5,400 timeshare resorts found in over 100 countries with over six million owners, ${ }^{13}$ compared to 506 resorts and 155,000 owners in $1980 .{ }^{6,14}$ Furthermore, this report noted that North America leads the timeshare industry worldwide in the number of resorts (31 per cent). The majority of these resorts are located in the United States. Europe (25 per cent) is the second largest market, followed by Latin America (16 per cent), Asia (14 per cent) and Africa (six per cent). The Caribbean region (six per cent) is one of the most popular international destinations for timesharing. ${ }^{13}$

The Caribbean region offers over 210 timeshare resorts. The Netherlands Antilles that includes Aruba, Saint Maarten, Curacao and Bonaire offers 22 per cent of the Caribbean total just after the leader in the region, the Dominican Republic (23.8 per cent). The Caribbean region as a whole generates a significant volume of sales with the Dominican Republic being the leader in timeshare sales and timeshare resort development. In terms of number of timeshare units, 56 per cent of timeshare resorts are located in only three islands: Aruba, Saint Maarten and the Dominican Republic. When measured in terms of sales volume (US\$), however, Aruba resorts dominated the market in 2003 with about one-third of all sales in the Caribbean. Also, Aruba timeshare owners have the greatest propensity to purchase multiple weeks versus owners from other Caribbean countries. ${ }^{15}$ In spite of its small size compared to other major islands of the region, Aruba has been a strong contender in the timeshare industry. First and foremost, tourism is the main contributor to the island's economy. It is the premier vacation spot in the Caribbean with 40 per cent of loyal visitors returning year after year, which is the highest repeat visitor rate of any Caribbean destination. ${ }^{16}$

\section{Need for study}

Collectively, there has been very little academic research conducted on the timeshare industry within the Caribbean region. In line with this paucity of empirical research, the popular tourist destination of Aruba has been 
void of academic studies concerning the state of the timeshare industry in spite of this industry's rapid growth. Therefore, this study is designed to profile the trends and patterns of the timeshare industry in general, within the Caribbean, and then specifically within Aruba. In doing so, this study contributes to the hospitality and tourism industry by profiling the present state of the timeshare industry in Aruba and culminates in a call for further timeshare research in the Caribbean, and in Aruba so that this phenomenon can be better understood from an impact perspective.

\section{BRIEF HISTORY OF THE TIMESHARE INDUSTRY}

The term timeshare refers to the right to purchase a specific time period in which a purchaser can use a unit within the timeshare resort at a geographical location of choice. ${ }^{17}$ The timeshare consumer is given exclusive rights to stay at a vacation-home type of experience in increments of a week or more. ${ }^{12}$

Timeshare began in Europe in the 1960s. ${ }^{8,12}$ The first ownership programme in the world was a ski resort located in the French Alps, known as 'Superdevoluy'. The purpose of this timeshare resort was to provide the owners of Superdevoluy with a definite opportunity to come and ski in the Alps on a repetitive basis. ${ }^{18}$ Superdevoluy therefore championed the concept of selling individual room units to multiple owners for a specified period of time of the year. ${ }^{19}$ The concept of selling individual resort units to multiple owners was quickly adopted in the US in the 1970s and specifically in Florida. ${ }^{13}, 17$ Since the industry's inception, the timeshare industry has recorded double-digit growth in less than two decades. ${ }^{11}$ The timeshare product has evolved in sales volume, number of owners, and independent and brand-name developers that have entered the field. The range of product lines and the diversity of product designs have also expanded over the years. ${ }^{17}$

During the 1980s and 1990s, major brand names in the hospitality and tourism industry pursued the timeshare industry. In 1984, Marriott was the first brand-lodging company to enter the timeshare industry, followed by Disney and Hilton. These companies brought brand-name recognition and had a strong influence on increasing consumer awareness and acceptance of the timeshare product through strict standard operating procedures, organisational performance standards, organisational views towards civic responsibility and adherence to strong business ethics. By the late 1990s, other major lodging companies, such as Starwood and Fairfield (Cendant), entered the industry. ${ }^{17}$

\section{TIMESHARE INDUSTRY IN THE CARIBBEAN}

According to the Resort Timesharing: In the Caribbean 2004 report, there were 214 resorts accounting for approximately 13,500 timeshare units located within the Caribbean. The Dominican Republic leads the region with 51 timeshare resorts and the Netherlands Antilles follows with 47 resorts and The Bahamas with 32 resorts. Overall, half of Caribbean timeshare units are located in the Netherlands Antilles or Dominican Republic. ${ }^{15}$ 
According to a study conducted by Interval International in 2000, the timeshare industry generated more than $\$ 1.2 \mathrm{bn}$ of economic impact throughout the Caribbean. As evidenced by this level of economic contribution, resort timesharing has emerged as one of the leading vacation preferences appealing to pleasure travellers visiting this region. In 2000, the average number of units per resort in the region was 114 , and the estimated average sales price for a timeshare interval was around $\$ 8,900$ per week/interval (excluding the Dominican Republic, which is representative of the influence of one-bedroom and studio inventory throughout the region). ${ }^{20}$

Given the above financial indicators, it can be ascertained that consumers are indeed attracted to the benefits associated with owning a timeshare resort unit. Who exactly are timeshare owners? Timeshare owners in the Caribbean tend to be married couples ( 82 per cent), aged between 45 and 54 years old ( 31 per cent), highly educated ( 68 per cent), empty nesters - meaning no children at home (40 per cent) and have annual household incomes greater than $\$ 50,000$ (98 per cent). In fact, nearly five in ten Caribbean timeshare owners report annual household incomes in excess of $\$ 100,000 .^{20}$

This same Interval International study also enquired into the factors that attracted consumers to purchase Caribbean timeshare resort units. The majority of respondents reported that the concept of exchange is the primary driver of their purchase decision. The basic concept behind an exchange is that a consumer can 'trade' their interval, often a week, with another owner for an equivalent unit at a different timeshare resort, at an equivalent resort, at a different destination. Other appealing factors noted in this report were satisfaction with the quality of resort's units and amenities ( 80 per cent), the assurance of a good value ( 72 per cent) per the money invested and the ability to save money on future accommodations (68 per cent). These findings suggest that the perceived value proposition remains a principal factor when motivating purchasers to consider purchasing the resort timeshare product. ${ }^{20}$

\section{TIMESHARE INDUSTRY IN ARUBA}

Since 1947, Aruba has been actively involved in tourism. ${ }^{21}$ Aruba lies south in the Caribbean region (Figure 1) outside the hurricane belt and enjoys the highest number of repeat visitors - close to 40 per cent - of any Caribbean destination. ${ }^{16}$ In 2005, 27.3 per cent of Aruba's visitors came twice to five times and 27.5 per cent visited the island of Aruba more than five times. Aruba has had a stable growing tourism economy. According to Vanegas and Croes,${ }^{21}$ Aruba has a very stable tourism economy where in 1975 there were 128,900 visitors who spent 986,200 nights. At that time, the average length of stay was 7.7 days with an occupancy rate of 74.2 per cent. In 2005, a total of 732,514 visitors visited the island of Aruba and spent a total 5,692,700 nights; the average length of stay was 7.9 days with an occupancy rate of 81.7 per cent. ${ }^{22}$ Table 1 captures the essence of this sustained growth of international visitation and impact upon Aruba from a 30-year perspective. In 2007, with a population close to 100,000 citizens, Aruba is clearly an attractive 


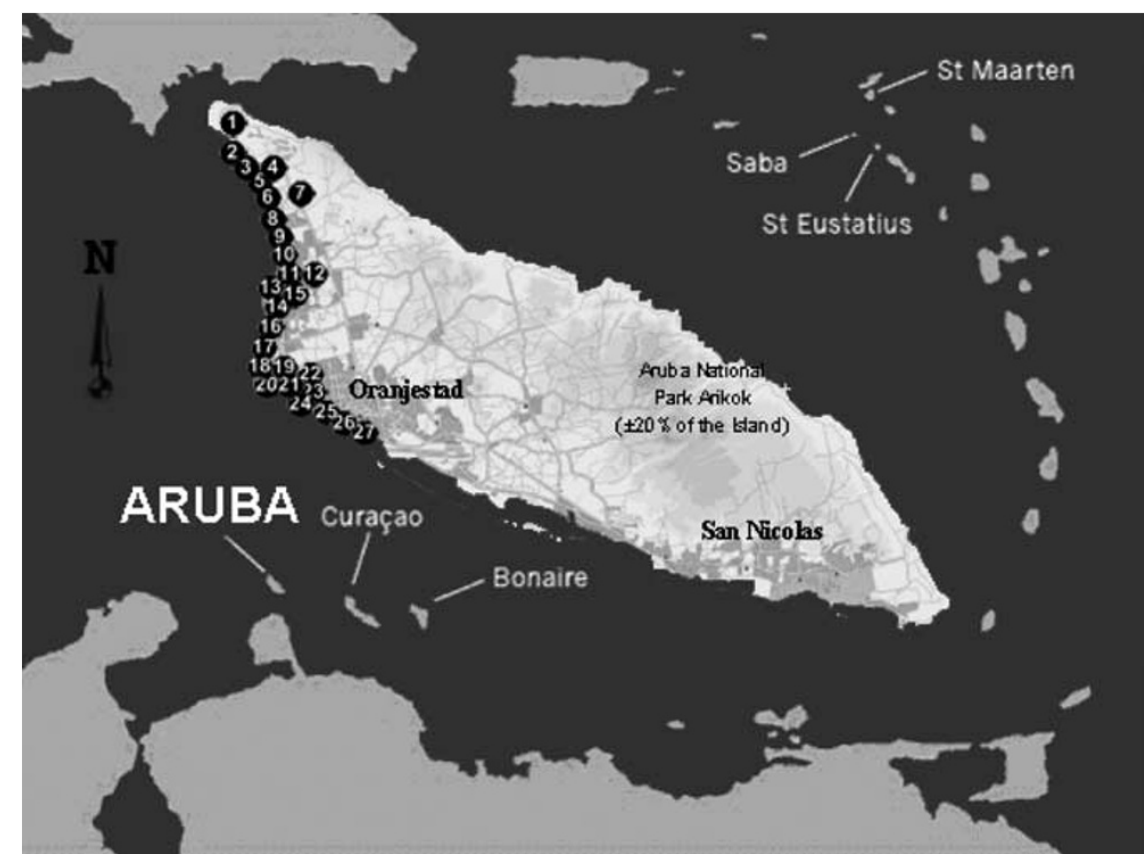

\begin{tabular}{|c|c|c|c|}
\hline \multicolumn{2}{|r|}{ High Rise Hotel } & \multicolumn{2}{|r|}{ Low Rise Hotel } \\
\hline (1) & Tierra Del Sol Villas Golf Club & 15 & Amsterdam Manor Beach Resort \\
\hline \multirow{3}{*}{2} & \multirow{3}{*}{$\begin{array}{l}\text { Marriott Resort \& Casino } \\
\text { Marriott Surf Club } \\
\text { Marriott Ocean Club }\end{array}$} & 14 & La Cabana \& Casino \\
\hline & & 16 & Paradise Beach Villas \\
\hline & & 17 & La Quinta \\
\hline 3 & Holiday Inn \& Casino & 18 & Costa Linda \\
\hline 4 & Brickell Bay & 19 & Bucuti Beach Resort \\
\hline 5 & Playa Linda Beach Resort & 20 & Manchebo Beach Resort \\
\hline 6 & Hyatt Regency \& Casino & 21 & Aruba Beach Club \\
\hline 8 & Caribbean Palm Village & 22 & Casa Del Mar \\
\hline 8 & Allegro \& Casino & 23 & Dutch Village \\
\hline $\boldsymbol{9}$ & Radisson \& Casino & 24 & Divi Village / Golf / Alhambra Casino \\
\hline 10 & Aruba Grand / Riu Hotel \& Casino & $(44)$ & Divi Aruba All Inclusive \\
\hline (11) & Westin \& Casino & 25 & Tamarijn Hotel \\
\hline$(2)$ & The Mill & 26 & Bushiri Hotel \\
\hline$(13$ & Divi Phoenix Aruba & 27 & Renaissance Suites \& Casino \\
\hline 27 & Renaissance Beach Resort \& Casino & T & Talk of the Town (Close to Airport) \\
\hline
\end{tabular}

Figure I: Aruba location and lodging industry. Displays a listing of high-rise hotel and low-rise hotels located on the island of Aruba. There are a total of 27 high- (multiple storey) and low-rise (single storey) accommodations, both traditional and timeshare resorts located on the western coastline of Aruba

destination to international visitors with that group contributing significantly to Aruba's $\$ 2.258$ bn GDP. ${ }^{24}$ The incremental increases in the number of international tourist arrivals, nights spent in Aruba, average length of stay, occupancy rate and tourism receipts indicate that Aruba has grown significantly from international visitation and their attraction to tourism products and services available in that country (Table 1).

In 1980, Aruba had 1,926 rooms with close to 5,000 direct and indirect jobs. ${ }^{21}$ Figure 1 displays the geographical locations of timeshare developments in Aruba of which all 23 properties are located on the western border of Aruba. In terms of percentage of room 
Table I: Aruba tourism trends in 1975 and 2005

\begin{tabular}{llllll}
\hline Year & $\begin{array}{l}\text { International } \\
\text { tourist arrivals } \\
\text { (thousands) }\end{array}$ & $\begin{array}{l}\text { Nights spent } \\
\text { (thousands) }\end{array}$ & $\begin{array}{l}\text { Average length } \\
\text { of stay (days) }\end{array}$ & $\begin{array}{l}\text { Occupancy } \\
\text { rate (\%) }\end{array}$ & $\begin{array}{l}\text { Tourism } \\
\text { receipts } \\
\text { (million) }\end{array}$ \\
\hline 1975 & 128.9 & 986.2 & 7.7 & 74.2 & 101.0 \\
1985 & 206.7 & 1363.0 & 6.6 & 80.5 & 226.5 \\
1995 & 618.9 & 4473.1 & 7.2 & 70.8 & 931.8 \\
2000 & 721.2 & 5247.8 & 7.3 & 76.0 & 1538.3 \\
2005 & 732.5 & 5692.7 & 7.9 & 81.7 & 1938.5 \\
\hline
\end{tabular}

Source: Central Bureau of Statistics ${ }^{22}$; DSEMT ${ }^{23}$; Vanegas and Croes ${ }^{21}$

Table 2: Aruba lodging industry in transient and timeshare from 2005 to 2010

\begin{tabular}{lllllll}
\hline Year & Hotel & Timeshare & Rooms & $\begin{array}{l}\text { Hotel } \\
(\%)\end{array}$ & $\begin{array}{l}\text { Timeshare } \\
\text { (\%) }\end{array}$ & $\begin{array}{l}\text { Other } \\
\text { (\%) }\end{array}$ \\
\hline 2005 & 3,916 & 3,240 & 7,689 & 50.9 & 42.1 & 6.9 \\
2006 & 4,390 & 4,326 & 9,249 & 47.5 & 46.8 & 5.8 \\
2007 & 5,335 & 5,102 & 10,970 & 48.6 & 46.5 & 4.9 \\
2008 & 5,335 & 5,134 & 11,002 & 48.5 & 46.7 & 4.8 \\
2009 & 6,435 & 5,134 & 12,102 & 53.2 & 42.2 & 4.4 \\
2010 & 6,435 & 5,134 & 12,102 & 53.2 & 42.4 & 4.4 \\
\hline
\end{tabular}

Source: Aruba Tourism Authority (ATA)

Table 3: Aruba rooms, arrivals, growth, occupancy rate, cost per visitors, cost per room and marketing investment from 2005 to 2010

\begin{tabular}{lccccccc}
\hline Year & Rooms & Arrivals & $\begin{array}{l}\text { Growth } \\
\text { (\%) }\end{array}$ & $\begin{array}{l}\text { Occupancy } \\
\text { (\%) }\end{array}$ & $\begin{array}{l}\text { Cost per } \\
\text { visitor }\end{array}$ & $\begin{array}{l}\text { Cost per } \\
\text { room }\end{array}$ & $\begin{array}{l}\text { Marketing } \\
\text { investment }\end{array}$ \\
\hline 2005 & 7,569 & 732,514 & 0.9 & 81.7 & 40.95 & 3,599 & $27,244,035$ \\
2006 & 7,689 & 736,177 & 0.5 & 78.7 & 40.75 & 3,902 & $30,000,000$ \\
2007 & 9,249 & 846,603 & 15.0 & 79.8 & 48.90 & 4,487 & $41,499,610$ \\
2008 & 10,970 & 922,797 & 9.0 & 73.3 & 51.35 & 4,711 & $51,682,696$ \\
2009 & 11,002 & $1,015,077$ & 10.0 & 80.4 & 53.91 & 4,947 & $54,425,130$ \\
2010 & 12,102 & $1,096,283$ & 8.0 & 79.0 & 56.61 & 5,194 & $62,859,986$ \\
\hline
\end{tabular}

Source: Aruba Tourism Authority ${ }^{16}$. Travel and Tourism in Aruba, Aruba Tourism Authority

accommodations, Table 2 denotes three observations: first is that the total number of hotel and timeshare room accommodation have increased over the years; secondly, the percentage of timeshare units to total lodgingroom availability ranges from 42.1 per cent to a maximum of 46.8 per cent and third, the geographical location and appeal of island type of life, and the nature of interval ownership has made ownership of timeshare units a sought after commodity by international travellers. This latter fact also corresponds to traditional lodging accommodations as well (Table 2).

Furthermore, Table 3 indicates that the growth of hotel and timeshare room accommodations is projected to have direct economic impacts as a direct outcome of total arrivals, growth in expected room construction and increase in tourist arrivals, and occupancy rate increases. 
Of course, these increases are not without increased costs. In particular, cost per visitor, cost per room and the resultant allocation of marketing dollars are depicted to rise as well.

\section{A CALL FOR RESEARCH IN ARUBA}

Apparently the state of the timeshare industry is alive and well in Aruba but the fact remains that there are concomitant impacts associated with timeshare resort development that remain to be studied (Figure 2). Figure 2 takes a lifecycle approach to understanding consumer acceptance of the timeshare product through the product development stages of commonly labelled as introduction, growth, maturity, saturation and decline.

Per this product lifecycle model, destination characteristics have been collected by the Aruba Tourism Authority but little is known about consumer characteristics that are associated with marketing response, economic impacts, social impacts and environmental impacts. Therefore, the researchers of this study suggest that for timeshare to remain sustainable the related factors associated with destination, marketing, economic, social and environment impacts should be studied in depth.

Relative to destination impacts, a consistent set of metrics should be developed that can monitor the gross number of tourist visitations on an annual basis, growth in tourist visitations, capacity by accommodation type (hotel, timeshare, condominium, etc), occupancy, price for services, visitor demographic, purpose of visit, visitor image of services and local perception of tourists.

The factors that remain to be studied under the heading of marketing response encompass governmental planning and marketing goals, marketing expenditures, product array, promotional tactics, pricing points for products and services, and effectiveness and efficiency of distribution of marketing efforts.

One of the most critical and often controversial aspects of tourism development is that of economic impacts. In the case or Aruba, numerous detailed studies are needed to profile present and projected employment impacts, gross product index, return on investment to the national and local economies, required investments, ancillary revenue generation, influence upon import/export ratios and inflation rates.

It goes without saying that the growth of the tourist industry is associated with a plethora of studies surrounding social impacts. In terms of Aruba, psychologists, sociologists and anthropologists will undoubtedly design studies focusing on types of tourists, relationship upon natives and native cultures, influence upon lifestyles, mores and value systems, changing family structure, and safety, security and local crime rates.

Lastly, a whole array of environmental impacts is yet to be conducted concerning conservation of resources, conservation of Aruba's heritage, ecological disruptions, pollution impacts, infrastructure impacts, and erosion of soil and foliage. 
畒: Hahm etal.

\begin{tabular}{|c|c|c|c|c|c|}
\hline Impact analysis & Introduction & Growth & Maturity & Saturation & Decline \\
\hline & & & & & \\
\hline $\begin{array}{l}\text { ARUBA } \\
1947\end{array}$ & & & & after 2008 & \\
\hline SITUATION & $\begin{array}{l}\text { New trendy } \\
\text { destination }\end{array}$ & $\begin{array}{c}\text { More people } \\
\text { interested } \\
\text { Investment on } \\
\text { accommodation \& } \\
\text { facilities }\end{array}$ & $\begin{array}{c}\text { Maximum } \\
\text { visitation } \\
\text { Increasing } \\
\text { facilities }\end{array}$ & $\begin{array}{l}\text { Oversupply, } \\
\text { Original demand } \\
\text { moves }\end{array}$ & $\begin{array}{l}\text { Reduction of } \\
\text { demand Special } \\
\text { offers to boost } \\
\text { visitation }\end{array}$ \\
\hline & & ESTINATION CHA & TERISTICS & & \\
\hline $\begin{array}{l}\text { Visitors number of } \\
\text { tourists }\end{array}$ & Few & Many & Too Many & Many & Many \\
\hline Growth rate & Low & Fast growth & Fast growth & Slow growth & Decline \\
\hline $\begin{array}{l}\text { Accommodation } \\
\text { capacity }\end{array}$ & Very Low & Low & High & Very High & Very High \\
\hline Occupancy levels & Low & Very High & Very High & High & Low \\
\hline Prices of Services & High & Very High & High & Low & Very Low \\
\hline Visitor types & Drifters & Innovators & Innovators & Followers & $\begin{array}{c}\text { Cheap-mass } \\
\text { market }\end{array}$ \\
\hline Image and attractions & Low & Very High & High & Low & Very Low \\
\hline $\begin{array}{l}\text { Stakeholder role and } \\
\text { area attractiveness }\end{array}$ & Guests & Guests & Customers & Customers & Foreigners \\
\hline & & MARKETING R & PONSE & & \\
\hline Marketing Target & Awareness & Inform & Persuade & Persuade & $\begin{array}{l}\text { Loyalty/new } \\
\text { market }\end{array}$ \\
\hline Strategic focus & Expansion & Penetration & Defense & Defense & Reintroduce \\
\hline Marketing Expenditure & Growing & High & High & Falling & Consolidate \\
\hline Product & Basic & Improved & Good & Detoriorates & Decay \\
\hline Promotion & Introduction & Advertising & Travel Trade & Travel Trade & Travel Trade \\
\hline Price & High & High & Lower & Low & Below cost \\
\hline Distribution & Independent & Independent & Travel Trade & Travel Trade & Travel Trade \\
\hline & & ECONOMIC II & ACTS & & \\
\hline Employment & Low & High & Very High & High & Low \\
\hline Foreign Exchange & Low & Very High & Very High & High & Low \\
\hline $\begin{array}{l}\text { Profitability of private } \\
\text { sector }\end{array}$ & Negative & Growing & Very High & High & Decline \\
\hline Income of residents & Low & Very High & Very High & Low & Very Low \\
\hline Investments & Low & Very High & Very High & Low & Very Low \\
\hline State revenue \& taxes & Low & Very High & Very High & Low & Very Low \\
\hline Economic structure & Balanced & Tourism oriented & $\begin{array}{c}\text { Tourism } \\
\text { dominated }\end{array}$ & Tourism depended & $\begin{array}{l}\text { Unbalanced and } \\
\text { not self sufficient }\end{array}$ \\
\hline $\begin{array}{l}\text { Dependency on } \\
\text { intermediaries }\end{array}$ & Negligible & Low & High & Over-dependent & Over-dependent \\
\hline Imports & Low & Very High & Very High & Very High & High \\
\hline Inflation & Low & Very High & Very High & High & Low \\
\hline & & SOCIAL IMF & CTS & & \\
\hline Types of tourists & Allocentrics & Allocentrics & Midcentrics & Psychocentrics & Psychocentrics \\
\hline $\begin{array}{l}\text { Relationships between } \\
\text { locals and tourists }\end{array}$ & Euphoria & Apathy & Irritating & Antagonism & Final \\
\hline $\begin{array}{l}\text { Demographics at } \\
\text { destination }\end{array}$ & $\begin{array}{l}\text { Immigrations and } \\
\text { other residents }\end{array}$ & $\begin{array}{l}\text { Youth stays to } \\
\text { work in tourism } \\
\text { More balanced }\end{array}$ & Balanced & Balanced & $\begin{array}{c}\text { Immigrations as } \\
\text { no jobs available } \\
\text { and } \\
\text { Older residents }\end{array}$ \\
\hline $\begin{array}{l}\text { Migration to the } \\
\text { destination }\end{array}$ & Low & High & Very High & High & Low \\
\hline Crime at the destination & Low & High & High & Very High & Very High \\
\hline Family structure & Traditional & Effected & Modern & Modern & Modern \\
\hline & & ENVIRONME & IMPACTS & & \\
\hline $\begin{array}{l}\text { Environment and } \\
\text { landscape }\end{array}$ & Unspoilt & Improved & No respect & Polluted & Damaged \\
\hline $\begin{array}{l}\text { Conservation and } \\
\text { heritage }\end{array}$ & Unspoilt & Improved & No respect & Decay & Damaged \\
\hline Ecological disruption & Unspoilt & Improved & No respect & Decay & Damaged \\
\hline $\begin{array}{l}\text { Pollution related to } \\
\text { tourism }\end{array}$ & Negligible & Low & High & Very High & Very High \\
\hline Water pollution & Negligible & Low & High & ery High & Very High \\
\hline Congestion and traffic & Low & Low & Very HII & Very High & Low \\
\hline Erosion & Low & High & Very High & Very High & Very High \\
\hline
\end{tabular}

Figure 2: Areas of needed research using resort lifecycle model

Source: Buhalis $(2000)^{25}$ 


\section{Acknowledgements}

We acknowledge Mr Jan van Nes, General Manager of Playa Linda Beach Resort for his willingness to contribute sources and personal insights into this project.

\section{References}

1. ARDA International Foundation (1999). State of the U.S. Vacation Ownership Industry: The 1999 Report, American Resort Development Association, Washington, DC.

2. ARDA International Foundation (2006a). State of the Vacation Timeshare Industry: United States Study, American Resort Development Association, Washington, DC.

3. ARDA International Foundation (2006b). Resort Timeshare Consumers: Who They Are, Why They Buy, American Resort Development Association, Washington, DC.

4. Bascombe, A. (2006). Industry insight: OTE 2006 study in UK shows high satisfaction. Vacation Industry Review. October/December, p.14.

5. Kazanjian, J.R. (2000). Timeshare Industry Overview, http://www.resortadvisors.com/ timeshare_overview.htm\#TIMESHARE, accessed 15th April, 2007.

6. Powers, T. \& Barrows, C.W. (2006). Introduction to the Hospitality Industry, 6th edn. John Wiley \& Sons, Hoboken, NJ.

7. World Tourism Organization (UNWTO) (2006). Tourism Highlights - 2006 Edition, World Tourism Organization, Spain.

8. Walker, J.R. (2006). Introduction to Hospitality, 4th edn. Pearson Prentice-Hall, Upper Saddle River, NJ.

9. Unknown (2007). About the Timeshare Industry, http://www.arda.org/AM/Template. cfm?Section=Industry_Information, accessed 15th April, 2007.

10. Haylock, R. (1994). The European timeshare market: The growth, development, regulation, and economic benefits of one of tourism's most successful sectors. Tourism Management. 15 333-341.

11. Upchurch, R. (2002). Product design evolution in the vacation ownership industry: From fixed weeks to points and vacation clubs. Journal of Leisure Property. 2, 239-253.

12. Upchurch, R. \& Gruber, K. (2002). The evolution of a sleeping giant: Resort timesharing. International Journal of Hospitality Management. 21, 211-225.

13. Resorts Condominiums International (RCI) (2003). History of timeshare, http://www. rciaffiliates.com/industryOverview/timeshareHistory.asp, accessed 15th April, 2007.

14. Sparks, B., Butcher, K. \& Pan, G. (2007). Understanding customer-derived value in the timeshare industry. The Cornell Hotel and Restaurant Administration Quarterly. 48, 28-46.

15. NorthCourse (2004). Resort Timesharing: In the Caribbean, NorthCourse, Parsippany, NJ.

16. Aruba Tourism Authority (2007). Aruba Bonbini, Aruba Tourism Authority, Aruba, p. 1.

17. Upchurch, R. \& Lashley, C. (2006). Timeshare Resort Operations: A Guide to Management Practice, Elsevier Butterworth-Heinemann, Burlington, MA.

18. Baiman, G. \& Forbes, R. (1992). Vacation Timesharing: A Real Estate, Rapport Publishing, Ontario.

19. Trowbridge, K. (1981). Resort Timesharing, Simon and Schuster, New York.

20. Interval International (2002). Interval International Spearheads Study on Impact of the Caribbean Timeshare Industry, http://www.thetimesharebeat.com/2002/ts/nov/1120-03t.htm, accessed 10th April, 2007.

21. Vanegas, S. \& Croes, R. (2003). Growth, development and tourism in a small economy: Evidence from Aruba. The International Journal of Tourism Research. 5, 315-330.

22. Central Bureau of Statistics (2005). Tourist Profile 2005, Oranjestad, Aruba.

23. Department of Statistics and Economic Measurement of Tourism (DSEMT) (2005). Tourism Statistics and the Measurement of Timeshare. Department of Statistics and Economic Measurement of the World Tourism Organization, pp. 1-25.

24. Central Intelligence Agency (CIA) (2007). The World Factbook: Aruba, https://www.cia.gov/ library/publications/the-world-factbook/print/aa.html, accessed 15th April, 2007.

25. Buhalis, D. (2000). Marketing the competitive destination of the future. Tourism Management. $21,97-116$. 